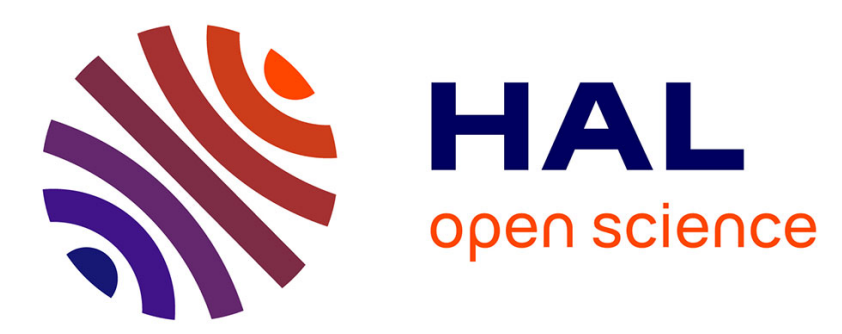

\title{
Emission and enrichments of radon daughters from Etna volcano magma
}

\author{
G. Lambert, P. Bristeau, G. Polian
}

\section{To cite this version:}

G. Lambert, P. Bristeau, G. Polian. Emission and enrichments of radon daughters from Etna volcano magma. Geophysical Research Letters, 1976, 3 (12), pp.724-726. 10.1029/GL003i012p00724 . hal03408248

\section{HAL Id: hal-03408248 \\ https://hal.science/hal-03408248}

Submitted on 29 Oct 2021

HAL is a multi-disciplinary open access archive for the deposit and dissemination of scientific research documents, whether they are published or not. The documents may come from teaching and research institutions in France or abroad, or from public or private research centers.
L'archive ouverte pluridisciplinaire HAL, est destinée au dépôt et à la diffusion de documents scientifiques de niveau recherche, publiés ou non, émanant des établissements d'enseignement et de recherche français ou étrangers, des laboratoires publics ou privés. 


\title{
EMISSION AND ENRICHMENTS OF RADON DAUGHTERS FROM ETNA VOLCANO MAGMA
}

\author{
G. Lambert, P. Bristeau and G. Polian ${ }^{+}$
}

Centre des Faibles Radioactivités, Laboratoire mixte CNRS-CEA

\begin{abstract}
A program of measurements in and outside the plume of Etna volcano has shown that radon daughters (as well as gaseous radon) are directly emitted from the magma. Enrichment factors have been observed : 4 for bismuth vs lead and 6 for polonium vs lead. The $210 \mathrm{~Pb}$ total output measured for the Etna plume is an insignificant source for this nuclide.
\end{abstract}

\section{Introduction}

According to Mroz and Zoller (1975), volcanic activity should be a significant source of particulate materials. These authors, as also Duce et al. (1975), Stoiber et al. (1974) have recently observed large enrichments in the trace elements composition of aerosols, fumarole deposits and other volcanic materials.

In the special case of lead, bismuth and polonium, volcanic emission can be approached by using the long lived decay products of $222_{\mathrm{Rn}}$ : nuclides $238 \mathrm{U} . . .222 \mathrm{Rn} \rightarrow{ }^{218} \mathrm{Po} \rightarrow{ }^{214} \mathrm{P}-\mathrm{Bi}-\mathrm{Po} \longrightarrow$ half-lives $\quad 3.8 \mathrm{~d}<3 \mathrm{mn} \quad 30 \mathrm{mn}$

$\rightarrow \underset{20 \mathrm{yr}}{210} \mathrm{~Pb} \underset{5 \mathrm{~d}}{210} \mathrm{Bi} \underset{138 \mathrm{~d}}{210 \mathrm{Po}} \rightarrow \begin{array}{r}206 \mathrm{~Pb} \\ \text { stable }\end{array}$

Emanation of gaseous radon is commonly observed during volcanic phenomena. Because of its short half-life, 218 Po will be in radioactive equilibrium with $22_{R n}$ a few minutes after emission, even though the formation of long half-life ${ }^{210} \mathrm{~Pb}$ (and its daughters) remains absolutely negligible after so short a time lag. Thus while some of the 218 Po associated with aerosols collected in the plume can be attributed to the decay of radon outgassed from the magma, essentially all of the long-lived radon decay products associated with this aerosol should have been directly emitted from the magma, where all the $238 \mathrm{U}$ daughters can be assumed to be in radioactive equilibrium.

\section{Procedures}

During June 1976 aerosol was collected on filters at various locations near the Etna vol -

+ also : Université de Picardie,

H also : Terres Australes et Antarctiques Françaises.

Copyright 1976 by the American Geophysical Union. cano (Sicily). The filters were cellulose Poelmann-Schneider and/or glass fiber Whatman GF/A filters, the air flow rate about $8 \mathrm{~m}^{3}$ per hour and sampling times 10 to 30 minutes. Volcanic activity was at low rate but several streams of lava were flowing along the North ern side.

A large number of filter samples were taken outside the plume at different altitudes inclu ding the top of the volcano, windward of the crater.

In addition, seven filters were sampled in side the plume despite technical difficulties such as lack of visibility and high concentrations of water vapour, $\mathrm{SO}_{2}$ and sulfuric acid in the air.

The gross $\alpha$ activity of the filters was moni tored immediately after the sampling and up to two months later. Gross $\beta$ activity was measured after returning to the laboratory, i.e. 5 to 10 days later. These measures were complemented by $\alpha$ spectrums whenever the long lived $a$ activity was sufficient.

Atmospheric concentrations of $222 \mathrm{Rn}$ and $220 \mathrm{Rn}$ and daughters were determined by means of the short lived $\alpha$ activity of the aerosols, as described previously (Lambert et al., 1972).

Data obtained are summarized in Table 1.

Radon 222

Outside the plume, ${ }^{222} \mathrm{Rn}$ concentrations varied between 20 and $80 \mathrm{pCi} / \mathrm{m}^{3}$ at the base camp (alt $1800 \mathrm{~m}$ ) and between 13 and $50 \mathrm{pCi} /$ $\mathrm{m}^{3}$ at the summit (alt $3000 \mathrm{~m}$ ) windward of the crater. This variation with altitude is smaller than usual, and can be attributed to the conti nuous flux of radon emitted from the slopes of the volcano.

Within the plume, filter samples were taken on the rim of the North-Eastern crater approximately 100 to $300 \mathrm{~m}$ above the level of the lava flow. The time-lag between the radon emission and the filtration in the plume was estimated to be a few minutes, thus, as discussed earlier, ${ }^{222} \mathrm{Rn}$ was essentially in radioactive equilibrium with 218Po in the plume. However, in three samples we have observed an apparent excess of $218 \mathrm{Po}$. This can be explained by the fact that the 218 Po concentrations indicated here 
characterize only the last five minutes of sampling.

Since the ${ }^{222} \mathrm{Rn}$ concentration in the plume was found to be of the same order of magnitude as in the surrounding atmosphere, outside the plume, this suggests that $222 \mathrm{Rn}$ emanation of the NE crater is of the same order of magnitude, or less, than the $222 \mathrm{Rn}$ emanation of the whole mountain.

\section{Lead, Bismuth and Polonium 210}

After 5 days of decay, negligible $\alpha$ and $\beta$ activities were observed for filters sampled outside the plume.

After the same time delay, filters sampled within the plume showed appreciable long-lived $\alpha$ and $\beta$ activities. An $\alpha$ spectrometry analysis indicated that the $\alpha$ activity was due solely to $210 \mathrm{Po}$. Consequently the observed $\beta$ activity cannot be attributed to $U$-Th daughters other than $210 \mathrm{~Pb}$ or $210 \mathrm{Bi}$. Similarly, the $\beta$ activity from $40_{K}$ can also be ruled out from the $\gamma$ spectrometry of the filters.

The $\beta$ activity study indicates the presence of two different components : the first of which had not decayed after two months and is attributed to $210 \mathrm{Bi}$ in radioactive equilibrium with $210 \mathrm{~Pb}$ (since the $\beta$ rays of $210 \mathrm{~Pb}$ have an energy too low to be detected). The second component decays with an half-life about 5 days and is attributed to an excess of $210 \mathrm{Bi}$, not balanced by $210 \mathrm{~Pb}$ desintegrations.

The concentrations of $210 \mathrm{~Pb}, 210_{\mathrm{Bi}}$ and $210 \mathrm{Po}$ in the plume are indicated in Table 1. It may be seen that these concentrations vary only slightly around $2,8.5$ and $12 \mathrm{pCi} / \mathrm{m}^{3}$, respectively.

Lead and Bismuth 212

The presence of 10.6 hour half-life ${ }^{212} \mathrm{~Pb}$ was also clearly evident in the plume. Concen- trations of this nuclide were close to zeo windward of the NE crater. Therefore the figures indicated in Table 1 are characteristic of the $212 \mathrm{~Pb}$ emanation of this crater.

There is also a good evidence for a direct emanation of 1 hour half-life $212 \mathrm{Bi}$.

It may be observed in Table 1 that the figures relative to the short lived nuclides vary from one sample to the other much more than for the long-lived nuclides. It seems therefore that the concentrations of $218 \mathrm{Po}, 212 \mathrm{~Pb}$ and $212 \mathrm{Bi}$ are under the dependence of transitory phenomena such as large bubbles burst. Therefore no conclusion can be drawn, at the moment, from the high value of the $212 \mathrm{~Pb} / 210 \mathrm{~Pb}$ ratio.

\section{Conclusions}

a- Owing to the long half-lives of ${ }^{210} \mathrm{~Pb}$ and $210 \mathrm{Po}$, these nuclides cannot be produced in the plume by the desintegration of $222 \mathrm{Rn}$ but are likely evaporated from the magma where temperatures are of the order of $1400^{\circ} \mathrm{K}$.

The first conclusion is the refore that active craters are not only sources of gaseous radon but also of radon daughters volatilized out of the magma.

b- As mentioned earlier, a secular equilibrium between $210 \mathrm{~Pb}, 210 \mathrm{Bi}$ and $210 \mathrm{Po}$, should exist in the lavas, but the activities measured in the plume are appreciably different. These nuclides are directly emitted from the magma, so the enrichements measured in the aerosols for the isotopes 210 may be considered representative of the enrichments of the total quantity (i.e. all isotopes) of each element in ques tion. The measured enrichments were (cf. Table 1) 4 for bismuth vs lead and 6 for polonium vs lead. These enrichments correlate with relative volatility of the elements and/or their different compounds. A more complete study would require better knowledge of the chemical state of these metals.

Table 1. Concentrations of Radon daughters in Etna plume.

\begin{tabular}{|c|c|c|c|c|c|c|c|c|c|c|}
\hline \multirow[b]{2}{*}{ Sample } & \multirow{2}{*}{$\begin{array}{c}\text { Date of } \\
\text { Sampling } \\
\text { June } 1976\end{array}$} & \multirow{2}{*}{$\begin{array}{l}\text { Volume } \\
\text { of air } \\
\left(\mathrm{m}^{3}\right)\end{array}$} & \multirow{2}{*}{$\begin{array}{l}{ }^{222} \mathrm{Rn} \\
\text { outside } \\
\text { the plume } \\
\left(\mathrm{pCi} / \mathrm{m}^{3}\right)\end{array}$} & \multicolumn{7}{|c|}{ Concentrations in the plume $\left(\mathrm{pCi} / \mathrm{m}^{3}\right)$} \\
\hline & & & & ${ }^{222} \mathrm{Rn}$ & $\begin{array}{c}\text { Excess of } \\
218_{\mathrm{Po}}\end{array}$ & $210 \mathrm{~Pb}$ & $210_{\mathrm{Bi}}$ & $210^{2} \mathrm{Po}$ & $212 \mathrm{~Pb}$ & $212_{\mathrm{Bi}}$ \\
\hline $\begin{array}{r}\text { CR } 1 \\
2 \\
3\end{array}$ & $\begin{array}{l}9 \\
9 \\
9\end{array}$ & $\begin{array}{l}1.4 \\
3.3 \\
0.8\end{array}$ & 22 & $\begin{array}{r}16 \\
? \\
(17)\end{array}$ & $\begin{array}{l}(27) \\
\text { small } \\
\text { small }\end{array}$ & $\begin{array}{r}2 \\
2 \\
1.7\end{array}$ & $\begin{array}{c}7 \\
5.8 \\
10.2\end{array}$ & $\begin{array}{l}20 \\
17.7 \\
20.8\end{array}$ & $\begin{array}{r}20 \\
5 \\
28\end{array}$ & $\begin{array}{c}\text { small } \\
? \\
(30)\end{array}$ \\
\hline $\begin{array}{l}10 \\
11\end{array}$ & $\begin{array}{l}12 \\
12\end{array}$ & $\begin{array}{l}0.7 \\
2.6\end{array}$ & 37 & $\begin{array}{c}53 \\
(16)\end{array}$ & $\begin{array}{l}\text { small } \\
(5)\end{array}$ & $\begin{array}{l}3.5 \\
2.2\end{array}$ & $\begin{array}{r}11.6 \\
9.4\end{array}$ & $\begin{array}{l}41.3 \\
18.5\end{array}$ & $\begin{array}{l}4 \\
7\end{array}$ & $\begin{array}{l}\text { smal1 } \\
(12)\end{array}$ \\
\hline $\begin{array}{l}20 \\
21\end{array}$ & $\begin{array}{l}14 \\
14\end{array}$ & $\begin{array}{l}0.8 \\
1.9\end{array}$ & 22 & $\begin{array}{l}69 \\
23\end{array}$ & $\begin{array}{l}\text { small } \\
(32)\end{array}$ & $\begin{array}{c}? \\
1.2\end{array}$ & $\begin{array}{c}? \\
8.7\end{array}$ & $\begin{array}{l}34.5 \\
13.1\end{array}$ & $\begin{array}{l}? \\
3\end{array}$ & $\begin{array}{c}\text { small } \\
?\end{array}$ \\
\hline
\end{tabular}

Data in parentheses give only an order of magnitude. 
c-Airflow of the Etna plume has been estimated to $10^{10} \mathrm{~m}^{3}$ per day by Zettwoog and col. (STEPAM French Commissariat à $1^{\prime}$ Energie Atomique), from $\mathrm{SO}_{2}$ composition and total output.

Using a mean $210 \mathrm{~Pb}$ concentration of $2 \mathrm{pCi} /$ $\mathrm{m}^{3}$ in this plume, we can estimate a total $210 \mathrm{~Pb}$ output of $2 \times 10^{-2} \mathrm{Ci}$ or $6 \times 10^{17}$ atoms per day. This is equivalent to the numbers of ${ }^{222} \mathrm{Rn}$ atoms emitted from $1000 \mathrm{~km}^{2}$ of land.

Thus, during a period of low volcanic activity, the $210 \mathrm{~Pb}$ output of the Etna plume has the same order of magnitude as the mountain "per se". If this is true for non explosive volcanic activity in general, then the $210 \mathrm{~Pb}$ atmospheric contribution from this source is negligible in comparison with the soil source.

Acknowledgments. Authors thank H. Tazieff and F. Le Guern's team, A. Jegou and P. Bourdon for their help during the sampling, J. Labeyrie, R. Chesselet and M. Kritz for helpful discussions.

\section{References}

Duce, R.A., G.I. Hoffman, W.H. Zoller, Atmospheric trace metals at remote Northern and Southern sites : pollution or natural ? Science, 187, 59-61, 1975 .

Lambert, G., B. Ardouin, G. Polian and J. Sanak, Radioactivity balance in the atmosphere of the Southern Hemisphere, in The Natural Radiation Environment, II, 787-807 (US-ERDA conf. 720805 P2, Houston), 1972.

Mroz, E.J., and W.H. Zoller, Composition of atmospheric particulate matter from the eruption of Heimaey, Iceland, Science, 190 , 461-464, 1975.

Stoiber, R.E., and W.I. Rose, Fumarole incrustations at active central American volcanoes, Geochim. Cosmochim. Acta, 38, 495-516, 1974 .

(Received July 12, 1976; revised september 7, 1976; accepted october 12, 1976.) 